\title{
Economic Optimization of Resource Use Based on Smart Grid ${ }^{*}$
}

\author{
Oleksandra V. Kubatko ${ }^{i}$, Vitaly M. Ignatchenko ${ }^{i i}$, Sergiy V. Shaparenko ${ }^{i i i}$, \\ IHOR A. STARODUB ${ }^{i v}$, DiANA O. Y YRYOMENKo ${ }^{v}$
}

\begin{abstract}
There are significant changes in society's approaches to the energy policy development in the modern world. It is observable a transition from the old model of the energy sector maintenance, which was dominated by large producers, inefficient networks, fossil fuels, imperfect competition in the markets of natural gas, coal, electricity - to a new model, which creates a more competitive environment and equalizes opportunities for development and the dominance one of the types energy production or sources of fuel supply. The traditional network is based on centralized power plants that supply electricity to consumers through simple one-way transmission and distribution systems. The bulk of the current electricity generation capacity in Ukraine is generated by fossil fuels, which significantly contributes to the increase of the carbon dioxide concentration in the Earth's atmosphere and has a corresponding negative consequences for the climate. At the same time, modern preferences are given to increasing energy efficiency and the use of energy from renewable and alternative sources. Implementation of adaptation and prevention measures for climate change is also one of the priorities of global energy development. The renewable energy promotion is causing new economic and scientific challenges for Ukraine. However, at the same time it opens new perspectives for the search and implementation of innovative developments in the field of extraction, processing of fossil fuels, energy supply and consumption, which leads to create a new energy policy of the state. The article discusses theoretical and methodological approaches that reveal the benefits of Smart Grid using. It is emphasized that ensuring energy security and environmental sustainability of the energy sector should be based on the use of renewable energy sources. The article analyzes the main factors that can affect the development of Smart Grid technology. Also, the article describes the best experience of the EU countries, which are introducing smart energy systems for the economic optimization of renewable energy sources use.
\end{abstract}

Keywords: Smart Grid, efficiency, optimization, renewable energy, economics growth, technology.

${ }^{i}$ Oleksandra V. Kubatko, PhD, Associate Professor, Department of Economics, Entrepreneurship and Business Administration, Sumy State University;

${ }^{i i}$ Vitaly M. Ignatchenko, PhD Student of the Department of Economics, Entrepreneurship and Business Administration, Sumy State University;

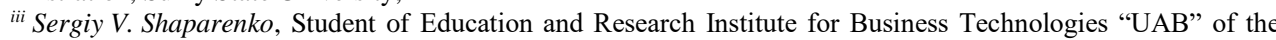
Sumy State University;

${ }^{i v}$ Ihor A. Starodub, Student, Oleg Balatskyi Academic and Research Institute of Finance, Economics and Management, Sumy State University;

${ }^{v}$ Diana O. Yaryomenko, Student, Oleg Balatskyi Academic and Research Institute of Finance, Economics and Management, Sumy State University.

* This work was supported by the Ministry of Education and Science of Ukraine (Project No. 0119U100766 "The optimization model of smart and secure energy grids building: an innovative technologies of enterprises and regions ecologisation").

(C) O. V. Kubatko, V. M. Ignatchenko, S. V. Shaparenko, I. A. Starodub, D. O. Yaryomenko, 2020.

https://doi.org/10.21272/mer.2020.88.03

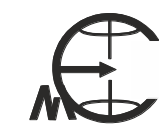


О. В. Кубатко, В. М. Ігнатченко, С. В. Шапаренко, І. А. Стародуб,

Д. О. Ярьоменко. Економічна оптимізація використання ресурсів на основі Smart Grid

Introduction. The implementation of Smart Grid technology should take into account the peculiarities of scientific, technical and technological state of generating sources, transmission systems and distribution of electricity in different countries. For example, today in the United States, the service life of $70 \%$ transformer substations and power lines is 25 years or more, which determines the task in accordance with the need for modernization and development of modern power network [1]. The similar is true for the domestic economy and the energy transition is crucial for the growth of Ukraine to guaranty the improvement of living standards, creating opportunities to increase the competitiveness of Ukrainian companies and their own production, promoting Ukraine in the world rankings of freedoms and business.

The study of global trends shows, that the main factors of energy system development are energy efficiency, security of energy supply, energy security and environmental harmonization. At the same time, increasing the degree of energy efficiency is a strategic direction to reduce the energy intensity of the economy. One of the key and driving motives for energy development for the period 2020-2040 should be the prevention of global climate change through a systematic reduction of greenhouse gas emissions. An important role is given to innovative Smart Grid technologies in combination with technologies of "intelligent" concepts of accounting and calculations (Smart Metering), demand management (Demand Response), energy storage devices and charging electric vehicles in the successful solution of urgent energy problems, including meeting the growing demand.

The purpose of article is to analyze the main factors that can affect the development of Smart Grid technology. The task of article: analysis experience of the different countries, which are introducing smart energy systems for the economic optimization of the use of renewable energy sources

Research results. The statistical review "Statistical Review of World Energy 2019", published by British Petroleum, provides an overview of the state and forecast of the global energy market, demand and supply of energy resources in the world. Analyzing the data "Statistical Review of World Energy 2019" we can consider the general picture of the dynamics of the global energy consumption balance, where the oil still remains the most used fuel in the energy mix. Coal is the second largest fuel but lost share in 2018 to account for $27 \%$. It was the lowest level during the last 15 years. The share of natural gas increased to $24 \%$ such that the gap between coal and gas has narrowed to $3 \%$. The contribution of hydro and nuclear remained relatively flat in 2018 at $7 \%$ and $4 \%$, respectively. Strong and constantly growth pushed up renewables share to $4 \%$. Thus, it can to emphasize that the consumption of electricity from renewable sources is growing every year.

At the present time, the Ukrainian economy remains one of the least energy efficient in the world. Other countries of the world, in particular the EU countries, have significantly reduced energy consumption over the past 20 years. But in Ukraine a significant part of energy recourses is spent inefficiently due to old equipment, depreciation of fixed assets and inefficient housing and communal services.

The positive experience of foreign countries in the field of energy efficiency is reflected in world rankings and indicators of energy intensity of GDP. The most countries around the world are rapidly implementing smart power systems, which are formed in the context of the Smart Grid concept and use smart technologies to ensure an efficient energy saving model. According to the report "2018 International Energy Efficiency Scorecard" of the American Council for Energy Saving, identified the countries that the better save electricity [3]. Thus, according to the rating, Germany and Italy take first place with a score of 75.5 points out of 100. France received 3rd place with a score of 73.5 points, next followed by Great Britain and 
Oleksandra. V. Kubatko, Vitaly M. Ignatchenko, Sergiy V. Shaparenko,

Ihor A. Starodub, Diana O. Yaryomenko. Economic Optimization of Resource use Based on Smart Grid

Japan. The United States has shifted by two positions compared to 2016. Other countries are arranged in the following order: Canada, Mexico, South Korea, Poland, India, Turkey, Indonesia, Australia, Ukraine and others. Germany has maintained its leading position since 2014 owing to the energy plan - Energiewende. In addition, the state aims to completely stop emissions of $\mathrm{CO}_{2}$ into the environment by 2050 .

It should also be noted that an important argument in favor of promoting energy efficiency is the investment that governments of countries support. Also, important factor of energy efficiency stimulation are policies to save money of householders, reduce dependence on energy imports and pollution [4]. That is why the introduction of technology of Smart grid is of paramount importance, as it helps to increase energy efficiency and increase the share of RES in the overall energy balance of the country. Features of implementation of Smart Grid technologies have certain advantages, in particular:

- guaranteeing uninterrupted operation of the power grid;

- reduction of electricity losses due to the introduction of the concept of "smart" metering with electricity quality assessment;

- formation of a communication sphere that can support high-quality and reliable bilateral exchange of information between energy consumers and suppliers;

- improving the quality of electricity with the help of technological devices and automated systems for monitoring the quality of electricity;

- use of energy storage of the required volume in order to equalize the load schedule;

- development of market relations in the energy business.

Continuing to analyze the issues of energy efficiency, in particular the efficiency of energy use in international rankings, we should pay attention to the ranking of countries, established by the Global Energy Architecture Performance Index (EAPI).

In general, the Global Energy Efficiency Index (EAPI) is a composite indicator to analyse specific indicators for determine the performance of energy systems in 127 countries. The Global Energy Architecture Performance Index is based on 18 indicators. The obtained result is given in the form of an energy efficiency index, which makes it possible to determine the rating of countries from among other countries.

The resulting table with intermediate EAPI data is based on the statistical information of the World Economic Forum [5] (Table 1). The evaluation is carried out on a scale from 0 (worst result) to 1 (best result).

According to the above data in table 1, there is reason to believe that the highest indicators on the Global Energy Efficiency Index have such countries as Switzerland, Norway, Sweden, Denmark and France. Germany ranks only 19th in the ranking. Ukraine took 73rd place in the overall ranking. Ukraine's position in the ranking of countries in the world indicates the need to apply the experience of foreign countries in the implementation of "smart" technologies in energy.

Of practical interest in this area is the experience of Germany, which actively uses innovative technological processes of energy saving and alternative energy sources. There is a nationwide initiative of the 3 largest German companies - Schmack Biogas AG, SolarWorld $\mathrm{AG}$, Enercon $\mathrm{GmbH}$ for the widespread use of renewable energy sources based on modern equipment, taking into account the high requirements for power grids. Today, a third of all electricity in the country is generated from wind farms. Wind energy and solar account for about $31 \%$ of all electricity in the Germany. The share of nuclear power plants decreased by up to $13 \%$. Because the German government plans to shut down all nuclear power units by 
О. В. Кубатко, В. М. Ігнатченко, С. В. Напаренко, І. А. Стародуб,

Д. О. Ярьоменко. Економічна оптимізація використання ресурсів на основі Smart Grid

2025. The share of coal-fired power plants increased to $55 \%$. Also, Germany plans to increase electricity production from renewable sources by $65 \%$ by 2030 [6].

Table 1

Global energy efficiency indices (2017)

\begin{tabular}{|c|c|c|}
\hline № / country rating & Country & Index \\
\hline 1 & Switzerland & 0.80 \\
\hline 2 & Norway & 0.79 \\
\hline 3 & Sweden & 0.78 \\
\hline 4 & Denmark & 0.77 \\
\hline 5 & France & 0.77 \\
\hline 6 & Austria & 0.76 \\
\hline 7 & Spain & 0.75 \\
\hline 8 & Colombia & 0.75 \\
\hline 9 & New Zealand & 0.75 \\
\hline 10 & Uruguay & 0.74 \\
\hline 19 & Germany & 0.71 \\
\hline 73 & Ukraine & 0.58 \\
\hline & & \\
\hline 127 & Bahrain & 0.37 \\
\hline
\end{tabular}

*built on the basis of statistical data of the World Economic Forum [5]

An equally important indicator of global energy is the Energy Transition Index (ETI) - a fact-based rating designed to enable policy makers and businesses to shape the direction of a successful energy transition. The study of energy concepts based on the energy transition index is conducted annually in different countries and it is a part of the initiative of the World Economic Forum. The energy transition index determines the current efficiency of the state energy system and the readiness of the energy transition.

Energy transition means the transition of the global energy sector to use renewable energy sources, which will reduce $\mathrm{CO} 2$ emissions. It should be noted that the global energy transition is slow but steady. According to Table 2, it can be argued that the highest rates are Sweden, Switzerland, Finland, Denmark and Norway [7, 8].

Table 2

Global indices of energy transition (2020)

\begin{tabular}{|c|c|c|}
\hline № / country rating & Country & Index \% \\
\hline 1 & Sweden & 74.2 \\
\hline 2 & Switzerland & 73.4 \\
\hline 3 & Finland & 72.4 \\
\hline 4 & Denmark & 72.2 \\
\hline 5 & Norway & 70.5 \\
\hline 6 & Austria & 69.9 \\
\hline 7 & United Kingdom & 68.7 \\
\hline 8 & France & 68.0 \\
\hline 9 & Netherlands & 67.3 \\
\hline 10 & Iceland & \\
\hline
\end{tabular}

*built on the basis of statistical data of the World Economic Forum [5] 
Oleksandra. V. Kubatko, Vitaly M. Ignatchenko, Sergiy V. Shaparenko, Ihor A. Starodub, Diana O. Yaryomenko. Economic Optimization of Resource use Based on Smart Grid

Therefore, the application of Smart Grid technologies and energy transition by countries is based on the provisions of a fully integrated, self-renewable and self-regulating electricity concept. It should be noted that the use of Smart Grid at the global level combines a number of modern technologies, such as:

- concepts of energy regime management and power systems, including smart systems;

- concepts of electricity distribution automation for medium and low voltage classes (Distribution automation);

- Smart accounting and calculation and routine load management;

- Customer Information System;

- the concept of charging electric cars.

Smart Grid power grids use a variety of "smart" sensors, such as voltage sensors, load balancing sensors, two-phase sensors, dynamic power line sensors that increase power flow. The sensors in Smart Grid networks are needed to balance loads, increase efficiency, monitor the operation of the electronic grid and control two-way power flows [1]. In general, more than 27 types of sensors are used in Smart grid.

The implementation of the Smart Grid concept takes into account the requirements of all stakeholders - the state, the householders, the generating network companies, the manufacturer, etc. In this regard, the main features of the new power industry are taken into account:

- reliability and quality of energy supply;

- the effectiveness of all types of resources and technologies in the production, transmission, distribution and consumption of electricity;

- efficiency - optimization and differentiation of tariffs for energy supply with simultaneous reduction of system-wide costs for production and distribution of electricity;

- public availability - providing consumers with energy in accordance with the necessary parameters;

- reduction of negative impact on the environment.

It should also be noted that all these features should be considered as equal, regardless of their order and location, they are determined personally for any subject of the relationship (country, region, city, company, etc.) [9].

In current conditions more than 2.930 organizations from 50 countries around the world participate in Smart Grid projects. It should be noted that private investment is one of the most important sources of funding for Smart Grid projects. According to the source [1] the main investments in Smart Grid projects are concentrated in: Germany, Sweden, Denmark, Spain, France, Great Britain and Belgium. The leaders among the countries with a growing share of distributed generation of energy are the United States, Germany, Australia, Great Britain, and Japan. European countries can expect annual savings of about 7.5 billion euros through the introduction of new technologies.

Now Ukraine uses various energy sources, such as coal, oil, natural gas, nuclear energy, solar and wind energy, and hydropower. In recent years, the most popular in Ukraine are fossil resources, namely natural gas and coal, which together account for more than $60 \%$ of the energy balance. But it should be noted that at the same time due to changes in prices, new technologies and global trends, the share of alternative energy is gradually increasing [10]. For an illustrative example, you can analyse the capacity of thermal, solar, wind and hydropower plants. 
О. В. Кубатко, В. М. Іенатченко, С. В. Шапаренко, І. А. Стародуб,

Д. О. Ярьоменко. Економічна оптимізація використання ресурсів на основі Smart Grid

According to [8], the installed capacity of thermal power plants (TPPs) is about $62 \%$ of the total installed capacity of all electricity generation in Ukraine, but they produce only about $40 \%$ of electricity in the country (39.5\% in the first quarter of 2018).

The total capacity of hydropower plants (HPPs) and Hydro Accumulation Power Plants (PSPs) is 6.200 MW. But it should be noted that it is possible to increase it due to the completion of Tashlyk and Dniester PSPs, and the construction of Kakhovka HPP-2, but still in total it will increase by only 3.000 MW. The share of hydropower in electricity generation is $9-10 \%$ (9.1\% in the first quarter of 2018). However, the main goal of hydropower engineers, as far as capacity and water flow in rivers allow, is to maintain the stability of the Ukrainian power system in the variable part of the load schedule. Hydropower is the main manoeuvring capacity of Ukraine's energy system.

Recently, there has been a high attention around wind energy and solar, which can be largely explained by the Paris Agreement, which requires reducing carbon energy and focusing on renewable energy sources to avoid climate change. The progress of economic indicators of wind farms and solar farms is also obvious. But unfortunately, its final results are not so obvious. The prices of building materials for wind farms and power plants (silicon, lithium, etc.) are constantly changing and affects the development of these sources of electricity. It should also be taken into account that the service life of the main elements of wind and solar farms is 10-15 years, after which they must be replaced, which also has a significant impact on the economy.

However, the main problem for these sources is instability, which is why the installed capacity is so low: only $25 \%$ for wind farms and even lower for the solar, because everything depends on weather conditions, and solar power plants do not work at night. Because of this, there is a need to create backup capacity. Different countries have different backup standards: from 30 to $70 \%$ of the capacity of wind and solar farms. In addition, solve the problem of redundancy of energy by creating storage capacity. If there is wind and sun, then charge the batteries. There is no sun or wind - we use the accumulated electricity of the batteries. But even here there are significant disadvantages, because using batteries there are significant costs, limited resources, short service life (about 15 years) and problems with toxic waste [8].

In current conditions Ukraine has developed a project "New Energy Strategy of Ukraine until 2035: Security, Energy Efficiency, Competitiveness" (Strategy-35), which sets strategic guidelines for the development of Ukraine's fuel and energy complex until 2035. This strategy has a plan which consists of three stages:

Stage 1 until 2020 provides for:

- transition of the energy sector of Ukraine to market principles of functioning and competition, which stimulates the increase the economic efficiency of energy sector subjects and efficiency of use the energy resources by economic entities and society in general;

- elimination of Ukraine's critical dependence on energy supplies from monopoly sources, increasing the level of energy security by diversifying routes and sources of energy supply;

- $\quad$ Stage 2 until 2025 provides:

- integration of Ukraine's energy sector into EU energy markets and the European energy security system;

- ensuring the competitiveness of the national energy sector in the European energy market by creating favourable conditions for attracting investment and technical modernization of energy sector facilities;

Stage 3 until 2035 provides: 
Oleksandra. V. Kubatko, Vitaly M. Ignatchenko, Sergiy V. Shaparenko, Ihor A. Starodub, Diana O. Yaryomenko. Economic Optimization of Resource use Based on Smart Grid

- full-scale integration of the energy sector of Ukraine into the European energy market with the free movement of energy resources;

- investments and technologies, which will provide advanced renovation of energy sectors and increase the level of self-sufficiency in energy production.

Thus, the main task of Strategy-35 is to develop the concept of ensuring energy security of the country and guaranteeing a stable energy supply of the national economy and social needs in both normal and special conditions [11].

Conclusions. So, as the world experience of the energy industry shows, the priority areas today are: timely investment in the development of the network economy; construction of interconnectors and development of interstate cooperation; ensuring generation manoeuvrability; reforming markets to develop "flexible redundancy"; demand management (increasing demand flexibility); improving forecasting of production of solar and wind power plants; measures to regulate the generation / consumption of distribution networks; use of RES to balance networks.

Analysing foreign experience in ensuring energy efficiency at the regional level, it was found that at the present stage of development of European countries, more and more attention is paid to the introduction of Smart technologies for the economic optimization of use the renewable energy sources This approach makes it possible to fully apply all elements of the smart grid system. The basis for our further research is the analysis of criteria and parameters by which the selection of a test site for the implementation of the Smart Grid model in order to effectively implement these systems in some areas of Ukraine.

The "New Energy Strategy of Ukraine until 2035" introduced in Ukraine should, as a result, transform the state's fuel and energy complex from a troubled sector that needs constant national assistance into a modern, productive, competitive sector of the national economy capable of sustainable development in the long run.

Growing competition in the global energy market and rapid scientific and technological progress in the development of renewable energy sources expand Ukraine's opportunities to choose sources and routes of primary energy supply, optimize the energy mix and, in the long run - reduce greenhouse gas emissions.

\section{References}

1. (2018). Stan rozvytku smart grid [The state of development of the smart grid]. Retrieved from: https://ua.energy/wp-content/uploads/2018/04/1.-Stan-rozvytku-smart-grid.pdf [in Ukrainian].

2. BP Statistical Review of World Energy 2019, 68th edition. Retrieved from: https://www.bp.com/content/dam/bp/business-sites/en/global/corporate/pdfs/energyeconomics/statistical-review/bp-stats-review-2019-full-report.pdf.

3. The International Energy Efficiency Scorecard. Retrieved from: https://www.aceee.org/portal/national-policy/international-scorecard.

4. Kubatko, O. V., Tolok, T. S, Edafejimue, H. O. \& Almashaqbeh, I. Y. Al. (2019). Investments in Renewable Energy for Smart Grid Technology Development. Mechanism of Economic Regulation, 2, 97-105.

5. Global energy architecture performance index. Retrieved from: http://reports.weforum.org/globalenergy-architecture-performance-index-2017/table-of-rankings/.

6. Energy Trilemma Index. Germany. Retrieved from: https://trilemma.worldenergy.org/\#!/countryprofile?country $=$ Germany $\&$ year $=2018$.

7. Energy Transition Index 2020: from crisis to rebound. Retrieved from: https://www.weforum.org/reports/fostering-effective-energy-transition-2020.

8. Yak v elektroenerhetytsi Ukraini nareshti pereity vid vyzhyvannia do rozvytku [How in Ukraine's power industry to finally move from survival to development]. Retrieved from: 
О. В. Кубатко, В. М. Ігнатченко, С. В. Напаренко, І. А. Стародуб,

Д. О. Ярьоменко. Економічна оптимізація використання ресурсів на основі Smart Grid

https://www.ukrinform.ua/rubric-economy/2461714-ak-v-elektroenergetici-ukraini-naresti-perejtivid-vizivanna-do-rozvitku.html [in Ukrainian].

9. Smart Grid. Retrieved from: https://ua.energy/wp-content/uploads/2018/01/3.-Smart-Grid.pdf.

10. Proekt "Nova enepgetychna strategiya Ukrainy do 2035 r [Project "New energy strategy of Ukraine until 2035]. Retrieved from: http://mpe.kmu.gov.ua/minugol/doccatalog/document?id=245213112 [in Ukrainian].

11. Energetichna strategiya Ukrainy na period do 2035 r. (proekt) [Energy strategy of Ukraine for the period up to 2035 (project)]. http://www.nas.gov.ua/siaz/Ways_of_development_of_Ukrainian_science/article/15036.3.012.pdf [in Ukrainian].

12. Melnyk, L. G., \& Kovalov, B. L. (Eds). (2020). Proryvni tekhnolohii v ekonomitsi i biznesi (dosvid YES ta praktyka Ukrainy u svitli III IV I V promyslovykh revoliutsii) [Breakthrough technologies in economics and business (EU experience and practice of Ukraine in the light of III, IV and V industrial revolutions)]. SumDU. Retrieved https://essuir.sumdu.edu.ua/handle/123456789/79621 [in Ukrainian].

Manuscript received 27 February 2020

Экономическая оптимизация использования ресурсов на основе Smart Grid

АЛЕКСАНДРА ВИКТОРОВНА КУБАТКО,
ВИТАЛИЙ МИХАЙЛОВИЧ ИГНАТЧЕНКО**,
СЕРГЕй ВИТАЛЬЕВИЧ ШАПАРЕНКО
ИГОРЬ АНДРЕЕВИЧ СТАРОДУБ ${ }^{* * * *}$,
ДИАНА АЛЕКСАНДРОВНА ЯРЕМЕНКО

" кандидат экономических наук, доцент, старший преподаватель кафедры экономики, предпринимательства и бизнес-администрирования Сумского государственного университета, ул. Р.-Корсакова, 2, г. Сумы, 40007, Украина, тел.:00-380-542-332223, e-mail: o.kubatko@econ.sumdu.edu.ua

** аспирант кафедры экономики, предпринимательства и бизнес-администрирования Сумского государственного университета, ул. Р.-Корсакова, 2, г. Сумы, 40007, Украина, тел.:00-380-542-332223, e-mail: Ignatchenko91@e-mail.ua

**** студент специильности «Экономическая кибернетика», Учебно-научный институт бизнестехнологий «УАБС» Сумского государственного университета, ул. Петропавловская, 57, г. Сумы, 40030, Украина, тел.:00-380-542-665051, e-mail: serg_homenet@ukr.net

***** студент Учебно-научного института финансов, экономики и менеджмента имени Олега Балацкого Сумского государственного университета ул. Р.-Корсакова, 2, г. Сумыл, 40007, Украина, тел.: 00-380-542-332223, e-mail: istarodub7@gmail.com

****** студентка специальности «Экономика и бизнес» Сумского государственного университета, ул. Р.-Корсакова, 2, г. Сумьл, 40007, Украина, тел.: 00-380-542-332223, e-mail: dianasumy0705@gmail.com 
Oleksandra. V. Kubatko, Vitaly M. Ignatchenko, Sergiy V. Shaparenko, Ihor A. Starodub, Diana O. Yaryomenko. Economic Optimization of Resource use Based on Smart Grid

В мире происходят изменения в подходах к разработке энергетической политики. Осуществляется переход от старой модели энергетического сектора, в которой доминировали крупные производители, неэффективные сети, ископаемое топливо, несовершенная конкуренция на рынках природного газа, угля, электроэнергии, - к новой модели, которая создает более конкурентную среду и выравнивает возможности для развития, и доминирования одного из видов производства энергии или источников поставки топлива. Традиционная сеть основана на централизованных электростанциях, которые поставляют электроэнергию потребителям через простые односторонние системы передачи и распределения. Большая часть нынешних генерирующих мощностей в Украине использует в основном ископаемое топливо, что значительно способствует увеличению концентрации углекислого газа в атмосфере Земли с соответствующими негативными последствиями для климата. В то же время предпочтение отдается повышению энергоэффективности и использованию энергии из возобновляемых и альтернативных источников. Реализация мер по адаптации и предотвращению изменения климата также является одним из приоритетов развития мировой энергетики. Это создает новые экономические и научно-технические проблемы для Украины. Однако в то же время это открывает новые перспективы для поиска и внедрения инновационных разработок в области добычи, переработки ископаемого топлива, энергоснабжения и потребления, что приводит к необходимости создания новой энергетической политики государства.

В статье рассматриваются теоретические и методологические подходы, раскрывающие преимущества использования Smart Grid. Подчеркивается, что обеспечение энергетической безопасности и экологической устойчивости энергетического сектора должно основываться на использовании возобновляемых источников энергии. В статье анализируются основные факторы, которые могут повлиять на развитие технологии Smart Grid. Также статья посвящена опыту стран EC, которые внедряют интеллектуальные энергетические системы для экономической оптимизации использования возобновляемых источников энергии.

Ключевые слова: Smart Grid, ефективність, оптимізація, відновлювальна енергія, економічне зростання, технології.

Mechanism of Economic Regulation, 2020, No 2, 37-47

ISSN 1726-8699 (print)

Економічна оптимізація використання ресурсів на основі Smart Grid

ОЛЕКСАНДРА ВІКТОРОВНА КУБАТКО,

ВІТАЛІЙ МИХАЙЛОВИЧ ІГНАТЧЕНКО**,

СЕРГІЙ ВІТАЛІЙОВИЧ ШАПАРЕНКО ${ }^{* * *}$,

ІгоР АНДРІйОВИч СТАРОДУБ ${ }^{* * * *}$,

ДІАНА ОЛЕКСАНДРІВНА ЯРЬОМЕНКО

* кандидат економічних наук, доцент ,старший викладач кафедри економіки, підприємництва та

бізнес-адміністрування Сумського державного університету,

вул. Р.-Корсакова, 2, м. Суми, 40007, Украӥна,

тел.: 00-380-542-332223, e-mail: o.kubatko@econ.sumdu.edu.ua

** аспірант кафедри економіки, підприємництва та бізнес-адміністрування

Сумського державного університету,

вул. Р.-Корсакова, 2, м. Суми, 40007, Украӥна,

тел.: 00-380-542-332223, e-mail: Ignatchenko91@e-mail.ua

*** студент Навчально-наукового інституту бізнес-технологій «УАБС»

Сумського державного університету

вул. Петропавлівська, 57, Суми, 40030, Украӥна

тел.:00-380-542-665051,e-mail: serg_homenet@ukr.net 
О. В. Кубатко, В. М. Іенатченко, С. В. Шапаренко, І. А. Стародуб,

Д. О. Ярьоменко. Економічна оптимізація використання ресурсів на основі Smart Grid

\author{
***** студент Навчально-наукового інституту фінансів, економіки та менеджменту \\ імені Олега Балацького Сумського державного університету \\ вул. Р.-Корсакова, 2, м. Суми, 40007, Україна, \\ тел.: 00-380-542-332223, e-mail: istarodub7@gmail.com \\ ****** студентка спеціальності «Економіка и бізнес» кафедра економіки, підприємництва та \\ бізнес-адміністрування Сумського державного університету, \\ вул. Р.-Корсакова, 2, м. Суми, 40007, Україна, \\ тел.:00-380-542-332223,e-mail: dianasumy0705@gmail.com
}

У світі відбуваються зміни в підходах до розробки енергетичної політики. Здійснюється перехід від старої моделі енергетичного сектора, в якій домінували великі виробники, неефективні мережі, викопне паливо, недосконала конкуренція на ринках природного газу, вугілля, електроенергії, - до нової моделі, яка створює більш конкурентне середовище і вирівнює можливості для розвитку, і домінування одного 3 видів виробництва енергії або джерел постачання палива. Традиційна мережа заснована на централізованих електростанціях, які постачають електроенергію споживачам через прості односторонні системи передачі і розподілу $\epsilon$ неефективною. Велика частина нинішніх генеруючих потужностей в Україні використовує в основному викопне паливо, що значно сприяє збільшенню концентрації вуглекислого газу в атмосфері Землі з відповідними негативними наслідками для клімату. У той же час перевага віддається підвищенню енергоефективності та використання енергії 3 відновлюваних і альтернативних джерел. Реалізація заходів з адаптації та запобігання зміні клімату також є одним 3 пріоритетів розвитку світової енергетики. Це створює нові економічні та науково-технічні проблеми для України. Однак в той же час це відкриває нові перспективи для пошуку і впровадження інноваційних розробок в області видобутку, переробки викопного палива, енергопостачання та споживання, що призводить до необхідності створення нової енергетичної політики держави.

У статті розглядаються теоретичні та методологічні підходи, що розкривають переваги використання Smart Grid. Підкреслюється, що забезпечення енергетичної безпеки та екологічної стійкості енергетичного сектора має грунтуватися на використанні поновлюваних джерел енергії. У статті аналізуються основні фактори, які можуть вплинути на розвиток технології Smart Grid. Також стаття присвячена досвіду країн СС, які впроваджують інтелектуальні енергетичні системи для економічної оптимізації використання відновлювальних джерел енергії.

Ключові слова: Smart Grid, відновлювальна енергетика, економічні процеси, енергомережі, енергопостачання, ефективність, інвестиції.

\title{
JEL Codes: O11, P51
}

Tables: 2; References: 12

Language of the article: English

\section{Література}

1. Стан розвитку Smart grid 2018 [Електронний ресурс]. - Режим доступу : https://ua.energy/wpcontent/uploads/2018/04/1.-Stan-rozvytku-smart-grid.pdf.

2. BP Statistical Review of World Energy 2019, 68th edition [Електронний ресурс]. - Режим доступу : https://www.bp.com/content/dam/bp/business-sites/en/global/corporate/pdfs/energyeconomics/statistical-review/bp-stats-review-2019-full-report.pdf.

3. The International Energy Efficiency Scorecard [Електронний ресурс]. - Режим доступу : https://www.aceee.org/portal/national-policy/international-scorecard

4. Kubatko, $O$. V. Investments in Renewable Energy for Smart Grid Technology Development / O. V. Kubatko, T. S Tolok, H. O. Edafejimue, I. Y. Al. Almashaqbeh // Механізм регулювання економіки. - 2019. - № 2. - С. 97-105.

5. Global energy architecture performance index [Електронний ресурс]. - Режим доступу: http://reports.weforum.org/global-energy-architecture-performance-index-2017/table-of-rankings. 
Oleksandra. V. Kubatko, Vitaly M. Ignatchenko, Sergiy V. Shaparenko, Ihor A. Starodub, Diana O. Yaryomenko. Economic Optimization of Resource use Based on Smart Grid

6. Energy Trilemma Index. Germany [Електронний ресурс]. - Режим доступу : https://trilemma. worldenergy.org/\#!/country-profile?country=Germany\&year=2018.

7. Energy Transition Index 2020: from crisis to rebound [Електронний ресурс]. - Режим доступу : https://www.weforum.org/reports/fostering-effective-energy-transition-2020.

8. Як в електроенергетиці України нарешті перейти від виживання до розвитку [Електронний pecypc]. - Режим доступу: https://www.ukrinform.ua/rubric-economy/2461714-ak-velektroenergetici-ukraini-naresti-perejti-vid-vizivanna-do-rozvitku.html.

9. Smart Grid [Електронний pecypc]. - Режим доступу: https://ua.energy/wpcontent/uploads/2018/01/3.-Smart-Grid.pdf.

10. Проект «Нова енергетична стратегія україни до 2035 року [Електронний ресурс]. - Режим доступу : http://mpe.kmu.gov.ua/minugol/doccatalog/document?id=245213112.

11. Енергетична стратегія України на період до 2035 р. [Електронний ресурс]. - Режим доступу : http://www.nas.gov.ua/siaz/Ways_of_development_of_Ukrainian_science/article/15036.3.012.pdf.

12. Проривні технології в економіці і бізнесі (досвід СС та практика України у світлі III, IV i V промислових революцій): навч. посіб. [Електронний ресурс] / за ред. Л. Г. Мельника та Б. Л. Ковальова. - Суми: СумДУ, 2020. - 180 с. - Режим доступу: https://essuir.sumdu.edu.ua/handle/123456789/79621. 